\title{
ПРОФІЛАКТИКА ОЖИРІННЯ У ПІДЛІТКІВ
}

\author{
А. С. Артеменко \\ ДвНЗ «Тернопільський державний медичний університет \\ імені I. Я. Горбачевського МОЗ Украӥни» \\ Нікопольський медичний коледж
}

У статті описано основні принципи профілактики ожиріння. Кожен зайвий кілограм маси тіла погіршує показники фізіологічного здоров’я і в результаті провокує появу нових захворювань. При своєчасному зверненні до лікаря і зміні способу життя можна запобігти або зменшити кількість негативних наслідків надлишкової маси тіла.

\section{PREVENTION OF OBESITY IN ADOLESCENTS}

\author{
A. S. Artemenko \\ I. Horbachevsky Ternopil State Medical University \\ Nikopol Medical College
}

The article describes the basic principles of prevention of obesity. Each extra kilogram of weight worsens the performance of physiological health and eventually provokes the development of new diseases. In case of a timely referral to a doctor and changing lifestyle, the child can prevent or slow down the negative effects of overweight.

Вступ. Ожиріння в підлітковому віці значно збільшується в усіх розвинутих країнах світу. Тому ця проблема набула великого розголосу. Вже не перше десятиліття спостерігають зростання числа дітей, які мають зайву масу тіла. Лікарі-педіатри та ендокринологи активно пропагують профілактику ожиріння: навчають батьків та дитину правильному харчуванню та фізичному навантаженню. Це набагато простіше, ніж лікувати запущену форму ожиріння та наслідки цієї хвороби. Варто зазначити, що ожиріння в дитячому віці створює підвищений ризик ожиріння в дорослому віці [1].

Основна частина. Попередження епідемії ожиріння серед дітей - це завдання, що вимагає титанічних зусиль батьків, представників медичної сфери та освіти.

ПЕРВИННА ПРОФІЛАКТИКА. Проводять серед здорових дітей. Така профілактика найефективніша, коли спрямована на все підростаюче покоління. Оскільки проблема ожиріння в більшості випадків починається з неправильного харчування, то першим кроком на цьому шляху має стати розуміння батьками важливості раціонального харчування в дитячому віці, ви- ховання правильних харчових пристрастей у дітей, організації режиму дня дитини з обов'язковим включенням зарядки та прогулянок на свіжому повітрі.

Батькам важливо пам'ятати, якщо вони будуть харчуватися правильно, то і проблем у дітей з ожирінням не виникне, адже кожна дитина завжди бере приклад насамперед із рідних людей - мами і тата.

Медичним працівникам у заходах із боротьби 3 ожирінням належить провідна і координуюча роль. Необхідно також проводити лекції, семінари, відкриті заходи, розповсюдження брошур та стендів у навчальних закладах [2].

Первинну профілактику ожиріння необхідно проводити при генетичній і сімейній схильності, при схильності до розвитку захворювань, супутніх ожирінню.

ВТОРИННА ПРОФІЛАКТИКА ОЖИРІННЯ. ВИмагає активної участі сімейних лікарів та медичних сестер. Залучення дієтологів, нутриціологів, ендокринологів, педіатрів має сприяти ранньому виявленню ожиріння та попередженню його наслідків та ускладнень. Дитина з надлишковою масою тіла зазвичай рідко звертається за медичною допомогою для боротьби з ожирінням [3-5]. Проте в медичній практиці, навіть

\footnotetext{
(C) А. С. Артеменко, 2019
} 
якщо пацієнт не виявляє скарг, корисним буде скринінговий метод оцінки стану здоров'я [6].

Велике значення в профілактиці ожиріння у дітей має правильне вигодовування в період життя до одного року. Своєчасне догодовування також має важливе значення. Неправильне вигодовування дітей молодшого віку підвищує відсоток так званих «гіпертрофіків» і «паратрофіків», які $є$ безпосередніми кандидатами на ожиріння. До групи ризику належать діти зі спадковою схильністю до ожиріння, діти з великою масою тіла при народженні, діти, які отримують штучне вигодовування, і діти, які надмірно додають у масі тіла на першому році життя.

Профілактичні заходи включають контроль за харчуванням вагітних, які годують груддю, проведення гімнастики, масажів, а також роз'яснювальну роботу з виховання здорової дитини.

Підлітку з надлишковою масою тіла необхідно пояснити правила збалансованого харчування як щодо калорійності, так і його складу. Батьків та дитину необхідно навчити як розрізняти низько-, помірно- і висококалорійні продукти. Продукти, що рекомендують до споживання без обмеження, мають забезпечити відчуття насичення (нежирні сорти м'яса, риби), задовольнити потреби в солодкому (ягоди, чай з цукрозамінником), створити відчуття наповнення шлунка (овочі). Раціон харчування необхідно збагачувати продуктами з ліполітичними властивостями (огірки, ананаси, лимон) і які збільшують термогенез (зелений чай, негазована мінеральна вода, морепродукти). До програми зі зниження маси тіла необхідно включати не тільки дієтичну корекцію, а й обов'язкові аеробні фізичні тренування, що дозволить підвищити або зберегти якість життя. Найефективніші втручання, спрямовані на корекцію ожиріння, охоплюють поєднання активних консультацій з корекції харчування, дієти і вправ із поведінковими стратегіями, спрямованими на те, щоб допомогти пацієнтові придбати відповідні навички.

Практично в 95 \% випадків не вдається на тривалий час зменшити масу тіла, оскільки ожиріння сприймається багатьма пацієнтами швидше як косметична, а не медична проблема. Ось чому більшість огрядних пацієнтів проводить самолікування. За даними Міжнародної групи з боротьби з ожирінням, кожен третій пацієнт, який страждає від ожиріння, намагається самостійно зменшити масу тіла, але без істотного ефекту [7].

І система харчування, і фізичні навантаження потребують ретельного, добре продуманого та індивідуального дозування. Але часто, коли лікар висловлює батькам проблему їхньої дитини (надлишкова маса тіла), сприймають це як образу і некомпетентність лікаря. Не до кінця усвідомлюють і те, що лікування ожиріння повинно мати безперервний характер. Тобто комплекс заходів, спрямованих на активне зменшення надлишкової маси тіла, ні в якому разі не повинен закінчуватися поверненням дитини до звичайного для неї та ії сім'ї харчування і способу життя. Вона має плавно переходити до комплексу заходів, спрямованих на підтримку досягнутого результату.

Висновки. Ожиріння в дитячому і підлітковому періодах $\epsilon$ серйозним і проблематичним питанням сучасності. Мета профілактики: попередити розвиток ожиріння в осіб із нормальною та надлишковою масою тіла, знизити ризик або запобігти розвиткові тяжких супутніх захворювань.

Показання до проведення профілактики: сімейна спадкова схильність до розвитку ожиріння та захворювань, що його супроводжують (цукровий діабет 2 типу, артеріальна гіпертензія, ішемічна хвороба серця), наявність ранніх факторів ризику метаболічного синдрому (гіперліпідемія, порушення толерантності до вуглеводів та ін.).

Роль медичних працівників полягає у навчанні підлітків та їхніх батьків веденню харчового щоденника та в допомозі по інтерпретації й правильній оцінці позитивної чи негативної динаміки антропометричних показників. Розпочинати боротьбу із ожирінням потрібно насамперед із себе. Опануйте основи нутриціології та нутриболоміки, купіть напольні ваги або монітор складу тіла, ведіть щоденник антропометричних показників, спожитих продуктів та їх енергетичної цінності. Показуйте підлітку гарний приклад щодо здорового способу життя та раціонального харчування. 


\section{СПИСОК ЛІТЕРАТУРИ}

1. Sugar sweetened beverages, obesity, type 2 diabetes and cardiovascular disease risk / V. S. Malik, B. M. Popkin, G. A. Bray [et al.] // Circulation. - 2010. - Vol. 23, No. 121 (11). - P. 1356-1364. - Mode access : https://www. ncbi.nlm.nih.gov/pmc/articles/PMC2862465.

2. Нечерда В. І. Ожиріння - глобальна проблема / В. І. Нечерда // Головна медична сестра. - 2017. - №1. C. 35-38.

3. Leach K. The overweight patient. A Psychological approach to understanding and Working with obesity / K. Leach. - London and Philadelphia : Jessica Kingsley Publishers, 2016. - 271 p.

4. Meta-analysis of the association between body mass index and health-related quality of life among adults, as- sessed by the SF-36 / Z. Ul-Haq, D. F. Mackay, E. Fenwick [et al.] // Obesity. - 2013. - Vol. 21, No. 3. - P. E322-E327.

5. Waumsley J. A. Obesity in the UK: A psychological perspective / J. A. Waumsley. - Leicester : St Andrews House, 2011. - 84 p.

6. Чопей І. В. Артеріальна гіпертензія. Сучасні діагностичні та лікувальні підходи у практиці сімейного лікаря / I. В. Чопей. - Ужгород : Говерла, 2013. - 228 с.

7. Haslam D. Fast facts.Obesity / D. Haslam, G. Wittert. Abingdon : Health Press Ltd, 2009. - 146 p.

8. Про затвердження норм фізіологічних потреб населення України в основних харчових речовинах і енергії [Електронний ресурс] : наказ МОЗ України від 03.09. 017 р. № 1073. - Режим доступу : http://zakon2.rada.gov.ua/laws/ show/z1206-17.

Отримано 13.02.19 